\title{
PETROGENESIS OF PRAIRIE CREEK LAMPROITES: CONSTRAINTS FROM MELT INCLUSIONS AND HIGH-PRESSURE EXPERIMENTS.
}

A. Girnis; I. Solovova; I. Ryabchikov and L. Kogarko.

urystaline, IIluid and melt microinclusions in minerals of Prairle Creek (USA, Arkansas) lamproites have been studied in order to obtain information about composition and crystalization conditions of melts. It was shown that snallow-level crystalization proceeded at temperatures 1050-1150\%, while olivine, clinopyroxene and Cr-spinel were iiquidus minerals. At this stage liquid was saturated by predominantly $\mathrm{CO}_{2}-\mathrm{H}_{2} \mathrm{O}$ fluid $\mathrm{with}_{\mathrm{CO}}$ pressure being more then 4 Kb. Silicate melts contain up to 14 wt.\% of $K_{2} O$ at about $7-9$ wt.\% MgO. Also typical are high concentrations of $\mathrm{P}, \mathrm{TI}, \mathrm{Ba}, \mathrm{F}$ and very high $\mathrm{K} / \mathrm{Al}$ ratio. Based on the chemistry of homogenized melt inciusions the composition of the least evolved liquid have been calculated - (wt.\%) $\mathrm{SiO}_{2} 44.1, \mathrm{TiO}_{2} 4.4, \mathrm{Al}_{2} \mathrm{O}_{3}$ 4.5, $\mathrm{F}^{\prime} \mathrm{OU}(\mathrm{t})$ 9.3, $\mathrm{MgO} 17.8$, CaO 3.8, $\mathrm{BaO} 1.5, \mathrm{~K}_{2} \mathrm{O} 9.9, \mathrm{Na}_{2} \mathrm{O} 2.4, \mathrm{P}_{2} \mathrm{O}_{5}$ 2.4. Similar ilquid must have been in equilibrium with mantle residual assemblage. Synthetic material of such composition nave been prepared and used in melting experiments conducted at 5-20 $\mathrm{kb}$ total pressure with pure $\mathrm{H}_{2} \mathrm{O}, \mathrm{H}_{2} \mathrm{O}-\mathrm{CO}_{2}$ Illuid as well as at Iluid absent conditions. At all parameters the Iirst crystaline phase is olivine. Further crystallization sequence depends criticaily on Iluid regime:

$$
\begin{array}{rl}
\text { ary } & \mathrm{OL}-\mathrm{OI}+\mathrm{OPX} \\
\mathrm{H}_{2} \mathrm{O} & \mathrm{OL}-\mathrm{OL}+\mathrm{PHL}-\mathrm{OI}+\mathrm{PHL}+\mathrm{CPX} \\
\mathrm{H}_{2} \mathrm{O}-\mathrm{CO}_{2} & \mathrm{OL}-\mathrm{OL}+\mathrm{OPX}-\mathrm{OI}+\mathrm{OPX}+\mathrm{PHL}
\end{array}
$$

Assuming that natural Illuid was predominantly a mixture of $\mathrm{CO}_{2}$ and $\mathrm{II}_{2} \mathrm{O}$, we conciude that initial lamproitic melts were in equilibrium with phlogopite-bearing harzburgitic residua. A Iittle amount of garmet probably was also retained in solid residua. Extrapolating phase equilibrium data the conditions of primary melt generation have been assessed - about $40 \mathrm{~kb}$ and $1400^{\circ} \mathrm{U}$. 